\title{
HAKEKAT KEADILAN PADA PENGADAAN TANAH UNTUK KEPENTINGAN UMUM DALAM RANGKA PEMBANGUNAN NASIONAL
}

\author{
Rahmad Masturi \\ Mahasiswa Program Doktor Ilmu Hukum Pascasarajana UMI Makassar \\ email :
}

\begin{abstract}
Land acquisition for the interest is done by way of deliberation in order to obtain agreement especially related to compensation issue. Although the empiric often occurs disagreement, which resulted in the clash between the holder of the land with the land holder land. The values of justice in the implementation of land procurement for the public interest have not been fully able to realize just law protection, so that the formation of Law No. 2 of 2012 on the procurement of land for public interest, can not be used as a means to achieve prosperity for all Indonesian people.

Keywords : Justice; Land Procurement; National Development;
\end{abstract}

\begin{abstract}
Abstrak
Pengadaan tanah untuk kepentingan tersebut dilakukan dengan musyawarah untuk mendapatkan kesepakatan terutama terkait dengan masalah kompensasi. Meskipun secara empiris sering terjadi perselisihan, yang mengakibatkan terjadinya bentrokan antara pemegang tanah dengan pemilik tanah. Nilai-nilai keadilan dalam pelaksanaan pengadaan tanah untuk kepentingan publik belum sepenuhnya mampu mewujudkan perlindungan hukum yang adil, sehingga pembentukan Undang-Undang Nomor 2 Tahun 2012 tentang pengadaan tanah untuk kepentingan umum, tidak bisa dijadikan sebagai sarana untuk mencapai kemakmuran bagi seluruh rakyat Indonesia.
\end{abstract}

Kata kunci: Keadilan; Pengadaan Tanah; Pembangunan Nasional;

\section{A. PENGANTAR}

Dasar konstitusional pengadaan tanah untuk kepentingan umum oleh Pemerintah diatur dalam Pasal 33 ayat (3) UUD NRI Tahun 1945 yang berbunyi: "Bumi dan air dan kekayaan alam yang terkandung di dalamnya dikuasai oleh Negara dan dipergunakan sebesar-besarnya untuk kemakmuran rakyat." Sebagi penjabaran dari Pasal 33 ayat (3) UUD NRI Tahun 1945 tersebut, diatur dalam Pasal 2 UUPA, yang menegaskan bahwa Hak Menguasai bukan berarti memiliki.

Dalam realitasnya peraturan perundang-undangan yang mengatur masalah pengadaan tanah, dianggap belum memenuhi rasa keadilan bagi pihak yang kehilangan tanahnya.Peraturan perundang-undangan yang telah diterbitkan tersebut, masih menghambat atau kurang untuk memenuhi kelancaran pelaksanaan pembangunan sesuai rencana. Karena itu, dengan diundangkannya Undang-Undang Nomor 2 Tahun 2012 tentang Pengadaan Tanah bagi Pembangunan untuk Kepentingan Umum,menjadi solusi 
atas pelaksanaan pengadaan tanah pada saat ini yang masih lambat dalam mendukung pembangunan infrastruktur. Pelaksanaan pengadaan tanah masih menimbulkan banyak permasalahan serta belum menjamin kepastian waktu dalam pembebasan tanahnya.

Sebagai peraturan pelaksanaan dari Undang-Undang Nomor 2 Tahun 2012 yang mengatur teknis pembebasan lahan, Presiden telah menerbitkan Perpres Nomor 71 Tahun 2012, telah diubah dengan Perpres Nomor 99 Tahun 2014, dan terakhir adalah Perpres Nomor 40 Tahun 2014 tentang Penyelenggaraan Pengadaan Tanah bagi Pembangunan untuk Kepentingan Umum.

Pengadaan Tanah untuk kepentingan umum mensyaratkan adanya ganti kerugian yang layak kepada pemegang hak atas tanah dan benda-benda yang ada di atasnya. Ganti kerugian tersebut merupakan hak masyarakat yang harus dilaksanakan oleh pemerintah sebagai pihak yang memerlukan tanah.Kepentingan masyarakat dan kepentingan perseorangan harus saling mengimbangi, sehingga akhirnya tercapai tujuan pokok, kemakmuran, keadilan dan kebahagiaan bagi rakyat seluruhnya.Namun seringkali proses ganti kerugian tersebut menimbulkan perselisihan dan pertentangan antara masyarakat yang tanahnya dibebaskan oleh Pemerintah, sehingga menimbulkan kerugian di kedua belah pihak. Di satu sisi rencana Pemerintah untuk membangun fasilitas umum menjadi terhambat, di sisi lain masyarakat menderita karena timbulnya ketidakpastian atas tanah mereka yang terkena pembebasan.

Maria S. W. Soemardjono, menekankan satu hal, yaitu prinsip keadilan dimana transaksi jual beli tanah yang berkeadilan adalah jika hasil yang diperoleh oleh pemilik tanah minimal setara dengan ketika tanahnyabelum dibeli Pemerintah. Bagaimana prinsip keadilan bisa berfungsi maka harus ada musyawarah dalam jual beli dengan memanfaatkan pejabat penilai tanah sebagai pemberi pertimbangan.prinsip keadilan ini bisa berjalan jika pemerintah juga punya etika berlaku adil.

\section{B. ANALISIS DAN PEMBAHASAN}

\section{Nilai-Nilai Keadilan Pada Pengadaan Tanah Untuk KepentinganUmum.}

Pengadaan tanah untuk kepentingan umum sering tidak dapat berjalan dengan baik, disebabkan karena pemegang hak atas tanah enggan melepaskan tanahnya, karena merasa tidak mendapatkan ganti kerugian yang layak.Karena itu,untuk mewujudkan nilai-nilai keadilan diperlukan adanya beberapa sarana penyelesaian, seperti mekanisme musyawarah dan mekanisme ganti kerugian.

\section{a. Mekanisme Musyawarah}

Musyawarah merupakan sarana yang digunakan negara untuk membuktikan itikad baik negara dalam menghormati hak milik masyarakat yang dijamin oleh konstitusi.Dalam Pasal 28H ayat (4) UUD NRI Tahun 1945 bahwa "hak milik perseorangan tidak dapat dirampas secara sewenang-wenang oleh siapapun". Perlindungan yang diberikan konstitusi dalam pengadaan tanah mencermikan nilai luhur musyawarah untuk menghindari tindakan pelanggaran hak asasi pemegang hak atastanah.

Dalam mekanisme musyawarah perlu didasarkan kepada prinsip-prinsip pengadaan tanah yang mencerminkan nilai keadilan, berupa prinsippenghormatan

Vol. 20 No. 2 November 2018 
terhadap hak-hak atas tanah yang dimiliki oleh rakyat yang merupakan bagian dari hak asasi warga Negara. Musyawarah itu sendiri merupakan kegiatan yang saling mendengar, memberi dan saling menerima pendapat, serta keinginan untuk mencapai kesepakatan mengenai bentuk dan besarnya ganti rugi dan masalah lain yang berkaitan dengan pengadaan tanah atas dasar kesukarelaan dan kesetaraan.

Namun dalam praktek, musyawarah sering tidak dapat dilakukan secara baik, oleh karena para pihak yang bermusyawarah tidak berada dalam kedudukan yang sama, sehingga lebih cenderung bersifat pengarahan. Menurut MariaS.W.Sumardjonobahwa walaupun secara prosedural musyawarah memenuhi syarat, namun apabila keputusan yang dihasilkan dilandasi adanya tekanan,maka tidak dapat dikatakan telah dicapai kesepakatan karena tekanan itu merupakan perwujudan dari pemaksaan kehendak satu pihak untuk menekan pihak lain agar mengikuti kehendaknya. Dengan kata lain kesepakatan itu terjadi dalam keadaan terpaksa, disamping itu, kehadiran atau keterlibatan orang-orang diluar kepanitiaan yang resmi yang tidak jelas fungsi atau tanggung jawabnya jelas akan semakin mengaburkan artimusyawarah itu secara substansial. ${ }^{1}$

Pengalaman masa lalu menunjukkan adanya kecenderungan bahwa yang dianggap sebagai musyawarah lebih dititik beratkan pada segi formalitas atau prosedur belaka.Padahal suatu musyawarah untuk dapat menghasilkan kesepakatan haruslah dilandasi asas kesejajaran antara pihak-pihak yang bermusyawarah dan dilaksanakan tanpa tekanan berupa apapun. ${ }^{2}$ Dalam Pasal 2 huruf f UU No. 2 Tahun 2012 bahwa yang dimaksud dengan "asas kesepakatan" adalah bahwa proses Pengadaan Tanah dilakukan dengan musyawarah para pihak tanpa unsur paksaan untuk mendapatkan kesepakatan bersama.

Seluruh kegiatan pengadaan tanah dilakukan berdasarkan kesepakatan antara pihak yang memerlukan tanah dan pemegang hak atas tanah. ${ }^{3}$ Kegiatan fisik pembangunan baru dapat dilaksanakan bila telah terjadi kesepakatan antara para pihak dan ganti rugi telah diserahkan.Prinsip penghormatan khususnya asas kesepakatan diejawantahkan dalam bentuk musyawarah.Musyawarah harus dilandasi dengan kesetaraan kedudukan para pihak.Di dalam musyawarah tidak boleh ada paksaan, tipuan, kekhilafan maupun penyalahgunaan keadaan. Proses musyawarah sama dengan proses negosiasi dalam suatu perjanjian di mana para pihak berusaha mempertemukan keinginan masing- masing untuk mencapai win-win solution.

Dalam UU No. 2 Tahun 2012 mengatur bahwa pelaksanaan musyawarah dilaksanakan dalam dua tahap.Tahap pertama, adalah konsultasi publik yang dilakukan untuk memperoleh kesepakatan lokasi rencana pembangunan.Pelaksanaannya dibatasi dalam jangka waktu 90 hari; danTahap kedua, adalah musyawarah penetapan ganti rugi. Musyawarah tersebut, dilaksanakan antara Badan Pertanahan Nasional (BPN) dengan pihak yang berhak paling lama 30 hari sejak hasil penilaian dari penilai disampaikan kepada BPN.

\footnotetext{
${ }^{1}$ Maria S.W.Sumardjono, "Tinjauan Yuridis Keppres No. 55 Tahun 1993 tentang Pengadaan Tanah Bagi Pelaksanaan Pembangunan Untuk Kepentingan Umum dan Pelaksanaannya”, (makalah, seminar nasional "pengadaan tanah untuk pembangunan, 1994), hlm. 6.

2 ibid.

${ }^{3}$ ibid.
}

Vol. 20 No. 2 November 2018 


\section{b. Mekanisme Ganti Kerugian}

Masalah ganti rugi merupakan isu sentral yang paling rumit penanganannya dalam upaya pengadaan tanah oleh pemerintah, hampir selalu muncul rasa tidak puas masyarakat yang hak atas tanahnya terkena proyek. Adapun bentuk ganti Kerugian yang diatur dalam UU No. 2 Tahun 2012 berupa : Uang, Tanah pengganti, Pemukiman kembali, Kepemilikan Saham, dan Bentuk lain yang disetujui oleh pihak- pihak yang bersangkutan.

Dalam hal tidak terjadi kesepakatan mengenai bentuk dan/atau besarnya ganti kerugian berdasarkan UU No. 2 Tahun 2012, pihak yang berhak dapat mengajukan keberatan kepada pengadilan negeri setempat dalam waktu paling lama 14 (empat belas) hari kerja setelah musyawarah penetapan Ganti Kerugian. Pengadilan negeri memutus bentuk dan/atau besarnya ganti kerugian dalam waktu paling lama 30 (tiga puluh) hari kerja sejak diterimanya pengajuan keberatan.Pihak yang keberatan terhadap putusan pengadilan negeri dalam waktu paling lama 14 (empat belas) hari kerja dapat mengajukan kasasi kepada Mahkamah Agung (MA) Republik Indonesia.MA wajib memberikan putusan dalam waktu paling lama 30 (tiga puluh) hari kerja sejak permohonan kasasi diterima.Putusan pengadilan Negeri/MA yang telah memperoleh kekuatan hukum tetap menjadi dasar pembayaran ganti kerugian kepada pihak yang mengajukan keberatan.

Ganti rugi dalam UU No. 2 Tahun 2012 ditetapkan pada Pasal 1 angka 10 bahwa Ganti Kerugian adalah penggantian yang layak dan adil kepada pihak yang berhak dalam proses pengadaan tanah. Dengan demikian, penekanan ganti rugi pada aspek kelayakan dan keadilan bagi pemegang hak atas tanah.

Ganti rugi yang harus diberikan dalam pengadaan tanah haruslah ganti kerugian yang adil, ${ }^{4}$ yang berarti bahwa pemberian ganti rugi tidak membuat seseorang menjadi lebih kaya, atau lebih miskin dari keadaan semula. Sedangkan yang dimaksud dengan ganti kerugian yang wajar dan layak, adalah besarnya ganti kerugian memadai untuk memperoleh tanah dan/atau bangunan dan tanaman di tempat lain. ${ }^{5}$

Konsep ganti rugi di dalam hukum perdata berbeda dengan konsep ganti rugi dalam peraturan pengadaan tanah.Ganti rugi dalam hukum perdata timbul manakala terjadi wanprestasi atau perbuatan melawan hukum.Ganti rugi dalam hukum perdata terdiri dari 3 macam, yaitu biaya, kerugian dan bunga. R.Subekti mendefinisikan tiga macam ganti rugi (schadevorgoeding) sebagai berikut $:^{6}$

1) Biaya (costen). Biaya adalah segala pengeluaran yang nyata-nyata sudah dikeluarkan oleh satu pihak;

2) Kerugian (schaden).Kerugian adalah kerugian kerusakan barang-barang kepunyaan satu pihak yang diakibatkan oleh kelalaian pihak lawan atau wanprestasi.

\footnotetext{
${ }^{4}$ ibid

${ }^{5}$ Adrian Sutedi, Implementasi Prinsip Kepentingan umum Dalam Pengadaan tanah Untuk pembangunan, Penerbit Sinar grafika: 2006. Jakarta, hlm. 265

${ }^{6}$ ibid
}

Vol. 20 No. 2 November 2018 
3) Bunga (interesten). Bunga adalah keuntungan bunga yang hilang yang mempunyai kemiripan dengan verlies yang diartikan sebagai kerugian yang berupa kehilangan keuntungan yang sudah dihitung oleh kreditur.

Ganti rugi dalam hukum pengadaan tanah tidak berkaitan dengan terjadinya wanprestasi atau perbuatan melawan hukum. Ganti rugi dalam hukum pengadaan tanah merupakan suatu kompensasi atas kerugian pemegang hak atas tanah yang kehilangan hak atas tanahnya, karena dibebaskan untuk kepentingan umum.

Asas-asas Ganti rugi harus diberikan kepada setiap orang yang berhak berdasarkan asas nemo plus yuris, yaitu pemegang hak atas tanah, pemilik bangunan maupun benda-benda yang ada dan melekat pada tanah. Ganti rugi merupakan hak mutlak dari para pemegang hak atas tanah yang melepaskan tanahnya untuk kepentingan umum.Tidak ada kewenangan pada negara untuk mengambil tanah tanpa adanya suatu ganti rugi.Indonesia bukan negara yang berideologi komunis yang memungkinkan penyitaan tanah tanpa ganti rugi.Penyitaan tanah hanya dimungkinkan bagi tanah-tanah hasil kejahatan.

Pada dasarnya harga jual beli dengan ganti rugi adalah sama. ${ }^{7}$ Perbedaan secara yuridis antara kedua istilah itu hanya dibedakan menurut perbuatan hukumnya.Jika dilakukan jual beli maka dibayarkan harga tanah.Sedangkan apabila dilakukan pembebasan tanah dibayarkan uang ganti rugi tanah.

Pemerintah masih memiliki interpretasi yang berbeda terhadap uang ganti rugi dan harga tanah.Ada yang mendefinisikan uang ganti rugi berbeda dengan harga tanah.Sebab pemerintah yang mengatur dan memberikan hak atas tanah, maka jika sebidang tanah diperlukan kembali oleh pemerintah cukup dibayar dengan uang ganti rugi bukan harga tanah.Jadi besarnya uang ganti rugi dengan sendirinya lebih rendah dari harga tanah.Pemerintah perlu mengubah pola pandangnya terhadap hakikat ganti rugi.Ganti rugi yang dibayarkan sebagai kompensasi pengadaan tanah haruslah mampu mengkompensasi kerugian yang diderita rakyat akibat pelepasan haknya.

Ganti rugi harus meliputi : ${ }^{8}$

a. Setiap kerugian akibat langsung dari pencabutan hak yang harus diganti sepenuhnya;

b. Kerugian disebabkan sisa yang tidak dicabut haknya menjadi berkurang nilainya;

c. Kerugian karena tidak dapat mempergunakan benda tersebut, atau karena kehilangan penghasilan;

d. Kerugian karena harus mencari tempat usaha lain sebagai penggantian.

Schenk mengemukakan lebih lanjut bahwa orang yang dicabut haknya harus dalam situasi finansil yang sama sebelum haknya dicabut, dan tidak di bawah dari

\footnotetext{
${ }^{7}$ John Salindeho, Masalah Tanah Dalam Pembangunan, Cetakan Kedua, (Jakarta: Sinar Grafika, 1988), 1994, hlm. 51.

${ }^{8}$ A.P. Parlindungan, Pencabutan dan Pembebasan Hak Atas Tanah Suatu Studi Perbandingan. Bandung: Mandar Maju 1993, hlm. 50
}

Vol. 20 No. 2 November 2018 
sebenarnya, sehingga dia mendapat kerugian. ${ }^{9}$

Dari perkembangan pengaturan bentuk dan dasar penentuan ganti rugi, seperti Peraturan Menteri Dalam Negeri No. 15 Tahun 1975 tidak diatur secara terperinci.Sedangkan di dalam Peraturan Presiden No. 36 Tahun 2005 menetapkan bentuk ganti rugisesuai Keputusan Presiden No. 55 Tahun 1993,dan mengubah dengan menambahkan penyertaan modal sebagai bentuk ganti rugi yang baru. Sementara itu, dalam Peraturan Presiden No. 65 Tahun 2006 bentuk ganti rugi dapat berupa:

a. Uang; dan/atau

b. tanah pengganti; dan/atau

c. pemukiman kembali; dan/atau

d. gabungan dari dua atau lebih dari bentuk ganti kerugian sebagaimana di maksud dalam huruf a, huruf $b$, dan huruf $c$.

e. bentuk lain yang disetujui pihak-pihak yang bersangkutan.

Bentuk ganti rugi dalam Peraturan Presiden No. 65 Tahun 2006 kembali mengacu kepada bentuk ganti rugi yang pernah diatur dalam Keputusan Presiden No. 55 Tahun 1993. Revisi penetapan ganti rugi diatur dalam Peraturan Presiden Nomor 65 Tahun 2006, yaitu: Dasar perhitungan besarnya ganti rugi didasarkan atas:

a. Nilai Jual Objek Pajak (NJOP) atau nilai nyata/sebenarnya dengan memperhatikan Nilai Jual Objek Pajak tahun berjalan berdasarkan penilaian Lembaga/Tim Penilai Harga Tanah yang ditunjuk oleh panitia;

b. Nilai jual bangunan yang ditaksir oleh perangkat daerah yang bertanggung jawab di bidang bangunan

c. Nilai jual tanaman ditaksir oleh perangkat daerah yang bertanggung jawab di bidang pertanian.

Perbedaan mendasar berkenaan dengan dasar perhitungan besarnya ganti rugi antara Peraturan Presiden Nomor 36 Tahun 2005 dengan Peraturan Presiden Nomor 65 Tahun 2006, adalah kewenangan penilai harga tanah untuk menetapkan jumlah ganti rugi. Di dalam Peraturan Presiden Nomor 36 Tahun 2005 penilai harga tanah berwenang untuk mengeluarkan penetapan mengenai besarnya ganti rugi tanah.Sedangkan di dalam Peraturan Presiden Nomor 65 Tahun 2006 penilai harga tanah hanya berwenang melakukan penilaian.Perubahan tersebut dikarenakan kewenangan penetapan ganti rugi ada pada panitia pengadaan tanah.

Di dalam Peraturan Kepala Badan Pertanahan Nasional No. 3 Tahun 2007 Pasal 28 ayat (2) diatur secara mendetail mengenai variabel-variabel yang turut dipertimbangkan dalam penetapan ganti rugi, antara lain: (2) Tim Penilai Harga

Tanah melakukan penilaian harga tanah berdasarkan pada NJOP, atau nilai nyata/sebenarnya dengan memperhatikan NJOP tahun berjalan, dan dapat berpedoman pada variabel-variabel sebagai berikut :

a. lokasi dan letak tanah; 
b. status tanah;

c. peruntukan tanah;

d. kesesuaian penggunaan tanah dengan rencana tata ruang wilayah atau perencanaan ruang wilayah atau kota yang telah ada;

e. sarana dan prasarana yang tersedia; dan

f. faktor lainnya yang mempengaruhi harga tanah.

Undang-Undang Nomor 2 Tahun 2012 dalam Pasal 36 mengatur mengenai bentuk ganti rugi berupa: Pemberian ganti kerugian dapat diberikan dalam bentuk:

a. uang

b. tanah pengganti

c. pemukiman kembali

d. kepemilikan saham

e. bentuk lain yang disetujui oleh kedua belah pihak.

Di dalam UU No. 2 Tahun 2012 tidak dicantumkan dasar penetapan ganti kerugian berdasarkan NJOP dan variabel-variabel penilaian harga tanah.Penilaian harga tanah sepenuhnya diserahkan kepada Penilai Pertanahan. Berdasarkan ketentuan Pasal 1 angka 11 yang dimaksud dengan Penilai Pertanahan adalah: Penilai Pertanahan, yang selanjutnya disebut Penilai, adalah orang perseorangan yang melakukan penilaian secara independen dan profesional yang telah mendapat izin praktik penilaian dari Menteri Keuangan dan telah mendapat lisensi dari Lembaga Pertanahan untuk menghitung nilai/harga objek pengadaan tanah.

Pembayaran ganti rugi yang adil dan layak dalam pengadaan tanah merupakan perwujudan dari prinsip penghormatan terhadap hak atas tanah.Keseimbangan antara kepentingan umum dengan kepentingan individu bergantung pada aspek kesebandingan nilai ganti rugi yang diberikan dengan kehilangan yang dialami pemegang hak atas tanah.

Ganti rugi dalam Peraturan Presiden Nomor 71 Tahun 2012 ditentukan bahwa "Penggantian yang layak dan adil kepada pihak yang berhak dalam proses Pengadaan Tanah". Penilai bertugas melakukan penilaian besarnya Ganti Kerugian bidang per bidang tanah, meliputi: a. tanah; b. ruang atas tanah dan bawah tanah; c. bangunan; $d$. tanaman; e. benda yang berkaitan dengan tanah; dan/atau f. kerugian lain yang dapat dinilai.

Adapun bentuk ganti rugi menurut UU No. 2 Tahun 2012 jo Perpres No. 71 Tahun 2012 bahwa Pemberian Ganti Kerugian atas Objek Pengadaan Tanah diberikan langsung kepada pihak yang berhak, yang pada prinsipnya harus diserahkan langsung kepada pihak yang berhak atas ganti kerugian. Apabila berhalangan, pihak yang berhak karena hukum dapat memberikan kuasa kepada pihak lain atau ahli waris. Penerima kuasa hanya dapat menerima kuasa dari satu orang yang berhak atas Ganti Kerugian, Yang berhak antara lain: a. Pemegang hak atas tanah;b. pemegang hak pengololaan; c. nadzir, untuk tanah wakaf;d. pemilik tanah bekas milik adat; e. masyarakat hukum adat;f. pihak yang menguasai tanah negara dengan itikad baik; g. pemegang dasar penguasaan atas tanah; dan/atau h. pemilik bangunan, tanaman atau benda lain yang Vol. 20 No. 2 November 2018 
berkaitan dengan tanah.

Ganti kerugian diberikan kepada pihak yang berhak berdasarkan hasil penilaian yang ditetapkan dalam musyawarah dan/atau putusan pengadilan negeri/Mahkamah Agung.Pada saat pemberian Ganti Kerugian pihak yang berhak menerima ganti kerugian wajib melakukan pelepasan hak dan menyerahkan bukti penguasaan atau kepemilikan Objek Pengadaan Tanah kepada instansi yang memerlukan tanah melalui Lembaga Pertanahan.Pihak yang Berhak menerima Ganti Kerugian Objek Pengadaan Tanah yang telah diserahkan kepada instansi yang memerlukan tanah menjadi tanggung jawab Pihak yang berhak menerima Ganti Kerugian.

Pemberian Ganti Kerugian menurut UU No. 2 Tahun 2012 ditentukan dalam hal Pihak yang Berhak menolak bentuk dan/atau besarnya Ganti Kerugian berdasarkan hasil musyawarah, atau putusan pengadilan negeri/MA, Ganti Kerugian dititipkan di pengadilan negeri setempat. Penitipan Ganti Kerugian, juga dilakukan terhadap: Pihak yang Berhak menerima Ganti Kerugian tidak diketahui keberadaannya; atau objek Pengadaan Tanah yang akan diberikan Ganti Kerugian : 1. Sedang menjadi objek perkara di pengadilan; 2. Masih dipersengketakan kepemilikannya; 3. diletakkan sita oleh pejabat yang berwenang atau 4. Menjadi jaminan di bank.

Pada saat pelaksanaan pemberian Ganti kerugian dan Pelepasan Hak telah dilaksanakan, atau pemberian Ganti Kerugian sudah dititipkan di pengadilan negeri, kepemilikan atau Hak Atas Tanah dari Pihak yang Berhak menjadi hapus dan alat bukti haknya dinyatakan tidak berlaku dan tanahnya menjadi tanah yang di kuasai langsung oleh negara. Pihak yang berhak menerima Ganti Kerugian atau instansi yang memperoleh tanah dalam Pengadaan Tanah untuk Kepentingan Umum dapat diberikan insentif perpajakan. Secara teknis bila terjadi penolakan atas bentuk dan besaran ganti rugi, maka pihak yang berhak dapat mengajukan keberatan kepada pengadilan negeri setempat dalam waktu paling lama 14 hari kerja setelah ditandatangani berita acara hasil musyawarah.

Bentuk ganti kerugian menurut Perpres No. 71 Tahun 2012 meliputi uang, tanah pengganti, pemukiman kembali. Kepemilikan saham atau bentuk lain yang disetujui oleh kedua belah pihak. Ganti kerugian dalam bentuk uang diberikan dalam bentuk mata uang rupiah.Pemberian ganti kerugian dilakukan paling lama 7 hari kerja sejak penetapan bentuk ganti kerugian oleh pelaksana pengadaan tanah.Ganti kerugian dalam bentuk tanah pengganti diberikan oleh instansi yang memerlukan tanah melalui pelaksana pengadaan tanah.Pemberian Ganti Kerugian dilakukan oleh Instansi yang memerlukan tanah setelah mendapat permintaan tertulis dari Ketua Pelaksana Pengadaan Tanah. Tanah pengganti diberikan untuk dan atas nama pihak yang berhak. Pelaksanaan penyediaan tanah pengganti dilakukan paling lama 6 bulan sejak penetapan bentuk ganti kerugian oleh pelaksana pengadaan tanah.Ganti Kerugian dalam bentuk permukiman kembali diberikan oleh Instansi yang memerlukan tanah melalui pelaksana pengadaan tanah.Pelaksanaan penyediaan permukiman kembali dilakukan paling lama 1 tahun.Ganti Kerugian dalam bentuk kepemilikan saham diberikan oleh Badan Usaha Milik Negara yang berbentuk perusahaan terbuka dan mendapat penugasan khusus dari Pemerintah. Pemberian Ganti Kerugian dalam bentuk lain yang disetujui oleh kedua belah pihak dapat berupa gabungan 2 atau lebih bentuk Ganti Kerugian. Ganti Kerugian tidak diberikan terhadap pelepasan hak objek 
pengadaan tanah yang dimiliki/dikuasai Pemerintah/BUMN/BUMD, kecuali objek pengadaan tanah yang telah berdiri bangunan yang dipergunakan secara aktif untuk penyelenggaraan tugas pemerintahan.Objek pengadaan tanah yang dimilik/dikuasai oleh BUMN/BUMD dan/atau objek pengadaan tanah kas desa. Tahapan pelaksanaan pengadaan tanah diatur dalam Pasal 27 ayat (1) UU No. 2 Tahun 2012 bahwa berdasarkan penetapan lokasi pembangunan untuk kepentingan umum, instansi yang memerlukan tanah mengajukan pelakksanaan pengadaan tanah kepada Lembaga Pertanahan. Dalam penjelasan Pasal 27 ayat (1) dijelaskan bahwa pengadaan tanah pada prinsipnya dilaksanakan oleh Lembaga Pertanahan, yang dalam pelaksanaannya dapat mengikutsertakan, atau berkoordinasi dengan pemerintah kabupaten/kota. Pelaksanaan pengadaan tanah dijelaskan dalam Pasal 27 ayat (2), ayat (3) dan ayat (4) yang prosesnya meliputi tahapan: inventarisasi dan identifikasi penguasaan, pemilikan, penggunaan, dan pemanfaatan tanah; penilaian ganti kerugian; musyawarah penetapan ganti kerugian; pemberian ganti kerugian; dan pelepasan tanah Instansi. Setelah penetapan lokasi pembangunan untuk kepentingan umum, pihak yang berhak hanya dapatmengalihkan hak atas tanahnya kepada instansi yang memerlukan tanah melalui Lembaga Pertanahan.Beralihnya hak dilakukan dengan memberikan Ganti Kerugian yang nilainya ditetapkan saat nilai pengumuman penetapan lokasi.

Selanjutnya dalam Pasal 2 Peraturan Presiden No. 71 Tahun 2012 dijelaskan bahwa Pengadaan Tanah untuk Kepentingan Umum diselenggarakan melalui tahapan:

a. perencanaan;

b. persiapan;

c. pelaksanaan; dan

d. penyerahan hasil.

Pada tahapan perencanaan menurut Pasal 3 Perpres No. 71 Tahun 2012 ditentukan bahwa setiap instansi yang memerlukan tanah bagi pembangunan untuk kepentingan umum membuat rencana pengadaan tanah yang didasarkan pada Rencana Tata Ruang Wilayah dan Prioritas Pembangunan yang tercantum dalam rencana pembangunan jangka menengah, rencana strategis dan rencana kerja pemerintah instansi yang bersangkutan. Tahapan persiapan, maka satu hal yang sangat penting untuk diperhatikan ialah adanya kewajiban untuk memberitahukan rencana pembangunan kepada masyarakat pada lokasi rencana pembangunan.

\section{Konsinyasi Dalam Pengadaan Tanah Untuk Kepentingan Umum}

Dalam Hukum Perdata konsinyasi diartikan sebagai penitipan uang di Pengadilan Negeri, yang dilatar belakangi adanya hubungan utang piutang antara debitur dengan kreditur.Dalam UU No. 2 Tahun 2012, tentang penitipan uang ganti kerugian diatur dalam Pasal 42 ayat (1) bahwa Dalam hal pihak yang berhak menolak bentuk dan/atau besarnya ganti kerugian berdasarkan hasil musyawarah, atau putusan Pengadilan Negeri/Mahkamah Agung,maka ganti kerugian dititipkan di pengadilan negeri setempat.Selain itu, penitipan ganti kerugian, juga dilakukan terhadap:

a. Pihak yang berhak menerima ganti kerugian tidak diketahui keberadaannya; atau

b. Objek Pengadaan Tanah yang akan diberikan Ganti Kerugian: 
1. sedang menjadi objek perkara di pengadilan;

2. masih dipersengketakan kepemilikannya;

3. diletakkan sita oleh pejabat yang berwenang;

4. menjadi jaminan di bank.

Selanjutnya dalam Pasal 43ditentukan bahwa :"Pada saat pelaksanaan pemberian ganti kerugian dan pelepasan hak telah dilaksanakan, atau pemberian ganti kerugian sudah dititipkan di pengadilan negeri, kepemilikan atau hak atas tanah dari pihak yang berhak menjadi hapus dan alat bukti haknya dinyatakan tidak berlaku dan tanahnya menjadi tanah yang dikuasai langsung oleh negara."

Secara garis besar konsinyasi, adalah penawaran pembayaran tunai diikuti dengan penyimpanan, yangdalam KUH Perdata ditentukan :

1. Pasal 1404 KUHPerdata menyatakan:

“jika si berpiutang menolak pembayaran, maka si berhutang dapat melakukan penawaran pembayaran tunai apa yang diutangkan, dan jika si berpiutang menolaknya, menitipkan uang atau barangnya kepada penagdilan. Penawaran yang sedemikian, diikuti dengan penitipan, membebaskan si berhutang dan berlaku baginya sebagai pembayaran, asal penawaran itu telah dilakukan dengan cara menurut undang-undang sedangkan apa yang dititipkan secara itu tetap atas tanggungan si berpiutang."

2. Pasal 1405 KUHPerdata menyatakan:“Agar supaya penawaran yang sedemikian itu sah adalah perlu :

a bahwa ia dilakukan kepada seorang berpiutang atau kepada seorang berkuasa menerimanya untuk dia;

b. bahwa ia dilakukan oleh seorang yang berkuasa membayar;

c. bahwa ia mengenai semua uang pokok dan bunga yang dapat ditagih, beserta biaya yang telah ditetapkan dan mengenai sejumlah uang untuk biaya yang belum ditetapkan, dengan tidak mengurangi penetapan terkemudian;

d. bahwa ketetapan waktu telah tiba, jika itu dibuat untuk kepentingan si berpiutang;

e. bahwa syarat dengan mana utang yang telah dibuat, telah dipenuhi;

f. bahwa pembayaran dilakukan di tempat, dimana menurut persetujuan pembayaran harus dilakukan, dan jika tiada suatu persetujuan khusus mengenai itu, kepada si berpiutang atau ditempat tinggal yang telah dipilihnya;

g. bahwa penawaran itu dilakukan oleh seorang Notaris atau juru sita, keduaduanya disertai dua saksi.

3. Pasal 1407 KUHPerdata menyatakan :

"biaya yang dikeluarkan untuk menyelenggarakan penawaran pembayaran tunai dan penyimpanan, harus dipikul oleh si berpiutang, jika perbuatan-perbuatan telah dilakukan menurut undang-undang."

4. Pasal 1408 KUHPerdata menyatakan : 
"selama apa yang dititipkan tidak diambil oleh si berpiutang, si berhutang dapat mengambilnya kembali dalam hal itu orang-orang yang turut berhutang dan para penanggung utang tidak dibebaskan."

Berdasarkan ketentuan tersebut di atas dapat disimpulkan beberapa hal, antara lain sebagai berikut :

a. Penawaran pembayaran tunai yang diikuti oleh penyimpanan (Konsinyasi) terjadi apabila dalam suatu perjanjian, kreditur tidak bersedia menerima prestasi yang dilakukan oleh debitur. Wanprestasi pihak kreditur ini disebut "mora kreditoris". ${ }^{10}$

b. Penawaran sah bilamana telah memenuhi syarat bahwa utang telah dibuat.Ini berarti bahwa penawaran hanya dikenal bila sudah ada hubungan hutang-piutang. Jelaslah bahwa lembaga konsinyasi bersifat limitatif. ${ }^{11}$

Konsinyasi yang dikenal di dalam Keppres No.55/Tahun 1993 hanyalah untuk keperluan penyampaian ganti rugi yang telah disepakati, akan tetapi orang yang bersangkutan tidak diketemukan. ${ }^{12}$ Peraturan pengadaan tanah ini, hanya berlaku bagi pengadaan tanah yang dilakukan oleh Instansi Pemerintah untuk kepentingan umum. Karena itu, konsinyasi hanya bisa diterapkan untuk pembayaran ganti rugi untuk pengadaan tanah dilakukan oleh Instansi Pemerintah untuk kepentingan umum, dengan catatan memang telah ada kesepakatan diantara kedua belah pihak: yang membutuhkan tanah dan pemegang hak atas tanah dan pemilik bangunan, tanaman dan/atau bendabenda yang ada di atas tanah tersebut. ${ }^{13}$

Berkenaan dengan pengadaan tanah untuk kepentingan umum, belum ada keseragaman pendapat boleh tidaknya konsinyasi diterapkan dalam pelepasan,atau penyerahan hak, sedangkan untuk pengadaan tanah yang dilakukan oleh swasta, para ahli menyatakan bahwa konsinyasi tidak dapat diterapkan dalam menyelesaikan ketidaksepakatan ganti rugi. Demikian pula Mahkamah Agung Republik Indonesia juga menegaskan melalui putusannya Reg. No. 3757 PK/Pdt/1991 tanggal 6 Agustus 1991 bahwa konsinyasi tidak dapat diterapkan dalam pengadaan tanah yang dilakukan oleh pemerintah. Konsinyasi hanya dikenal atau diatur dalam KUHPerdata dan Keppres No.55/Tahun 1993 yang sekarang telah dinyatakan tidak berlaku.

Peraturan Kepala BPN No 3/2007 tentang Ketentuan Pelaksanaan Perpres No 36/2005 yang telah diubah dengan Perpres No 65/2006 tentang Perubahan atas Perpres No 36/2005, yang berkaitan dengan konsinyasi adalah penilaian harga tanah oleh Tim Penilai Harga Tanah didasarkan pada NJOP atau nilai nyata dengan memerhatikan NJOP tahun berjalan, dan dapat berpedoman pada 6 (enam) variabel yakni lokasi, letak tanah, status tanah, peruntukan tanah, kesesuaian penggunaan tanah dengan RI'RW,

\footnotetext{
${ }^{10}$ Mariam Darus Badrulzaman, Kitab Undang-Undang Hukum Perdata Buku III tentang Hukum Perikatan dengan Penjelasan, Bandung, Alumni, 1983, hlm. 171.

${ }^{11}$ Oloan Sitorus, SKH Sinar Indonesia Baru, 6 Juli 1994, dalam Oloan Sitorus dan Dayat Limbong, Pengadaan Tanah Untuk Kepentingan Umum, Yogyakarta, Mitra Kebijakan Tanah Indonesia, 2004, hlm. 80.

${ }^{12}$ Abdulrrahman, Pengadaan Tanah Bagi PelaksanaanPembangunan UntukKepentingan Umum, Bandung, Citra Aditya Bakti, 1994, hlm. 66

${ }^{13}$ Oloan Sitorus dan Dayat Limbong, Op. Cit, hlm. 59.
} 
sarana dan prasarana, dan faktor-faktor lain.

Penilaian harga bangunan dan/atau tanaman dan/atau benda-benda lain dilakukan oleh instansi terkait.Hasil penilaian diserahkan kepada P2T untuk digunakan sebagai dasar musyawarah.Kesepakatan dianggap telah tercapai bila $75 \%$ luas tanah telah diperoleh, atau $75 \%$ pemilik telah menyetujui bentuk dan besarnya ganti rugi. Jika musyawarah tidak mencapai $75 \%$, maka dapat terjadi 2 (dua) kemungkinan, yakni:

1. Jika lokasi dapat dipindahkan, P2T mengusulkan kepada instansi pemerintah yang memerlukan tanah untuk memindahkan lokasi;

2. Jika lokasi tersebut tidak dapat dipindahkan (sesuai kriteria dalam Pasal 39), maka kegiatan pengadaan tanah tetap dilanjutkan. Jika $25 \%$ dah pemilik belum sepakat tentang bentuk dan besarnya ganti rugi atau $25 \%$ luas tanah belum diperoleh, P2T melakukan musyawarah kembali dalam jangka waktu 120 hari kalender. Jika jangka waktu 120 hari lewat, maka:

"Bagi yang telah sepakat mengenai bentuk dan besarnya ganti rugi, ganti rugi diserahkan dengan Berita Acara Penyerahan Ganti Rugi atau Berita Acara Penawaran Ganti Rugi.Bagi yang tetap menolak, ganti rugi dititipkan oleh instansi pemerintah di Pengadilan Negeri (PN) setempat berdasarkan Berita Acara Penyerahan Ganti Rugi.”

P2T Kabupaten/Kota membuat Berita Acara Hasil Pelaksanaan Musyawarah dan Penetapan Bentuk dan/atau besarnya ganti rugi yang ditandatangani oleh seluruh anggota P2T, instansi pemerintah yang memerlukan tanah dan para pemilik. Putusan P2T tentang bentuk dan/atau besarnya ganti rugi diatur dalam Pasal 40-42.Pemilik yang berkeberatan terhadap putusan P2T dapat mengajukan keberatan disertai alasannya kepada Bupati/WaliKota/Gub/Mendagri dalam waktu paling lama 14 (empat belas) hari.

Putusan penyelesaian atas keberatan diberikan dalam waktu paling lama 30 (tiga puluh) hari.Bila pemilik tetap berkeberatan dan lokasi pembangunan tidak dapat dipindahkan, Bupati/WaliKota/Gub/Mendagri mengajukan usul pencabutan hak atas tanah menurut UU No 20/1961.

Ganti rugi dalam bentuk uang diberikan dalam waktu paling lambat 60 (enam puluh) hari sejak tanggal keputusan.Untuk ganti rugi yang tidak berupa uang, penyerahannya dilakukan dalam jangka waktu yang disepakati para pihak.Ganti rugi diberikan dalam bentuk: (1) Uang;(2) Tanah dan/atau bangunan pengganti atau permukiman kembali;(3) Tanah dan/atau bangunan dan/atau fasilitas lainnya dengan nilai paling kurang sama dengan harta benda wakaf yang dilepaskan;(4) Recogniseberupa pembangunan fasilitas umum atau bentuk lain yang bermanfaat bagi kesejahteraan masyarakat setempat (untuk tanah ulayat), atau sesuai keputusan pejabat yang berwenang untuk tanah instansi pemerintah atau pemerintah daerah.

Penitipan ganti rugi karena sebab-sebab tertentu (Pasal 48), yakni:

1. Yang berhak atas ganti rugi tidak diketahui keberadaannya;

2. Tanah, bangunan, tanaman dan atau benda lain terkait dengan tanah sedang menjadi obyek perkara di pengadilan;

3. Sengketa pemilikan yang masih berlangsung dan belum ada penyelesaiannya;

Vol. 20 No. 2 November 2018 
4. Tanah, bangunan, tanaman dan benda-benda lain yang terkait dengan tanah sedang dfletakkan seta oleh pihak yang berwenang.

5. Penitipan ganti rugi dilakukan dengan permohonan penitipan kepada Ketua Pengadilan Negeri.

Perpres maupun Peraturan Kepala BPN No 3/2007 menyebutkan tentang bentuk ganti kerugian berupa permukiman kembali, namun tidak merincinya lebih lanjut. Sebagaimana diketahui, permukiman kembali itu merupakan proses tersendiri yang memerlukan perhatian mengenai berbagai hal, antara lain:bahwa pemilihan lokasi permukiman kembali harus merupakan hasil musyawarah dengan pihak yang akan dipindahkan dengan mengikutsertakan masyarakat penerima; lokasi pemindahan harus dilengkapi sarana dan prasarana serta fasilitas umum.Prasarana dan sarana tersebut harus dapat juga dimanfaatkan oleh masyarakat setempat. Demikian juga Perpres tidak menyinggung tentang ganti kerugian terhadap faktor nonfisik berupa upaya pemulihan pendapatan (income restoration).

\section{PENUTUP}

Pengadaan tanah untuk kepentingan dilakukan dengan cara musyawarah agar dapat diperoleh kesepakatan terutama berkaitan dengan persoalan ganti rugi. Kendatipun secara empiric sering terjadi ketidaksepakatan, yang berakibat timbulnya bentutran antara pemegang ha katas tanah dengan pihak yang memelukan tanah.

Nilai-nilai keadilan pada pelaksanaan pengadaan tanah untuk kepentingan umum belum sepenuhnya dapat mewujudkan perlindungan hukum yang berkeadilan, sehingga pembentukan UU No. 2 Tahun 2012 tentang pengadaan tanah untuk kepentingan umum, belum dapat dijadikan sebagai sarana dalam mewujudkan kesejahteraan bagi seluruh rakyat Indonesia.

\section{DAFTAR PUSTAKA}

Abdulrrahman, Pengadaan Tanah Bagi Pelaksanaan Pembangunan Untuk Kepentingan Umum, Bandung, Citra Aditya Bakti, 1994

Adrian Sutedi, Implementasi Prinsip Kepentingan umum Dalam Pengadaan tanah Untuk pembangunan, Penerbit Sinar grafika: 2006. Jakarta.

BF. Sihombing, Evolusi Kebijakan Pertanahan Dalam Hukum Tanah Indonesia, Jakarta: Gunung Aguns, 2005.

Djanggih, H., \& Salle, S. (2017). Aspek Hukum Pengadaan Tanah bagi Pelaksanaan Pembangunan untuk Kepentingan Umum. Pandecta: Research Law Journal, 12(2), $165-172$.

John Salindeho, Masalah Tanah Dalam Pembangunan, Cetakan Kedua, Jakarta: Sinar Grafika, 1988. 
Oloan Sitorus, SKH Sinar Indonesia Baru, 6 Juli 1994, dalam Oloan Sitorus dan Dayat Limbong, Pengadaan Tanah Untuk Kepentingan Umum, Yogyakarta, Mitra Kebijakan Tanah Indonesia, 2004.

Mariam Darus Badrulzaman, Kitab Undang-Undang Hukum Perdata Buku III tentang Hukum Perikatan dengan Penjelasan, Bandung, Alumni, 1983.

Maria S.W.Sumardjono, "Tinjauan Yuridis Keppres No. 55 Tahun 1993 tentang Pengadaan Tanah Bagi Pelaksanaan Pembangunan Untuk Kepentingan Umum dan Pelaksanaannya", (makalah, seminar nasional "pengadaan tanah untuk pembangunan, 1994.

Oloan Sitorus dan Dayat Limbong, Pengadaan Tanah Untuk Kepentingan Umum, Yogyakarta, Mitra Kebijakan Tanah Indonesia , 2004.

Rahman, S., \& Passamai, S. (2017). Regional Government Functions In Land Procurement For Development For Public Interest. ADRI International Journal Of Law and Social Science, 1(1), 10-17.

Parlindungan, Pencabutan dan Pembebasan Hak Atas Tanah Suatu Studi Perbandingan, Cetakan I. Bandung: Mandar Maju, 1993. 